\title{
Analisis Tipe Staphylococcal Cassette Chromosome mec (SCCmec) Isolat Methicillin Resistant Staphylococcus aureus (MRSA)
}

\author{
Sunarjati Sudigdoadi \\ Departemen Mikrobiologi Fakultas Kedokteran Universitas Padjadjaran
}

\begin{abstract}
Abstrak
Resistensi methicillin resistant Staphylococcus aureus (MRSA) terhadap berbagai antimikrob terutama didasari adanya insersi mobile genetic elements yang disebut Staphylococcal cassette chromosome mec (SCCmec) pada kromosom Staphylococcus aureus. SCCmec tersusun atas gen rekombinase (ccr), gen kompleks mec, gen resisten tambahan, dan insertion sequences. Struktur gen rekombinase memungkinkan SCCmec dapat berpindah dari satu bakteri ke bakteri lainnya. Identifikasi dan analisis SCCmec sangat diperlukan untuk mengetahui dasar genetik resistensi dan memperkirakan penyebaran bakteri ini. Penelitian ini bertujuan menganalisis tipe SCCmec dan hubungannya dengan pola kepekaan MRSA terhadap berbagai antimikrob. Penelitian ini adalah penelitian observasional analitik dengan pendekatan molekuler berupa typing SCCmec dan uji kepekaan terhadap antimikrob, periode Juli-Desember 2007. Pembiakan dan identifikasi 45 isolat MRSA dilakukan di Departemen Mikrobiologi Fakultas Kedokteran Unpad, sedangkan penentuan gen mecA dan PCR multipleks SCCmec dilakukan di Fakultas Kedokteran Universitas Sriwijaya, Palembang. Seluruh 45 isolat MRSA yang diteliti, dipastikan memiliki gen mecA. Analisis PCR multipleks menunjukkan 40 isolat memiliki SCCmec tipe III dan 5 isolat memiliki tipe IV. Semua isolat dengan SCCmec tipe III bersifat multiresisten, sedangkan tipe IV tidak bersifat multiresisten. Dapat disimpulkan bahwa MRSA dengan genotip SCCmec tipe III berhubungan, sedangkan tipe IV tidak berhubungan dengan sifat multiresisten. [MKB. 2010;42(4):149-54].
\end{abstract}

Kata kunci: Methicillin resistant Staphylococcus aureus (MRSA), pola kepekaan, tipe SCCmec

\section{Staphylococcal Casette Chromosome mec (SCCmec) Type Analysis of Methicillin Resistant Staphylococcus aureus (MRSA) Isolates}

\begin{abstract}
Resistance of methicillin resistant Staphylococcus aureus (MRSA) were based mainly on insertion of mobile genetic elements namely Staphylococcal cassette chromosome mec (SCCmec) in the chromosome of Staphylococcus aureus. SCCmec consists of recombinase genes (ccr), mec genes complex, additional resistance genes, and insertion sequences. Recombinase genes structure mediates transfer of SCCmec from one bacteria to another. Identification of SCCmec is very important to know basic genetic resistance and to predict spreading of MRSA. The aim of this research was to analyze SCCmec type and antimicrobial susceptibility patterns. The design of this study was observational analytic study by typing SCCmec and antimicrobial susceptibility testing on July- December 2007. Isolation and identification of 45 MRSA isolates was performed in the Department of Microbiology, Faculty of Medicine, University of Padjadjaran, whereas identification of mecA gene and typing of SCCmec by multiplex PCR was performed in the Department of Microbiology, Faculty of Medicine, Sriwijaya University, Palembang. The result showed that all isolates contained mecA gene. Multiplex PCR revealed that 40 MRSA isolates had SCCmec type III and 5 isolates with type IV. All SCCmec type III isolates were multiresistant and all of the type IV were not multiresistant. In conclusion, MRSA isolates with SCCmec type III was associated with multiresistant whereas type IV was not. [MKB. 2010;42(4):149-54].
\end{abstract}

Key words: Methicillin resistant Staphylococcus aureus (MRSA), susceptibility patterns, type of SCCmec

Korespondensi: Dr. Sunarjati Sudigdoadi, dr., MS., Sp.MK, Departemen Mikrobiologi Fakultas Kedokteran Universitas Padjadjaran, jalan Raya Bandung-Sumedang Km. 21 Jatinangor Sumedang, telepon (022) 7794557, mobile 0811225351, e-mail:titi_sa@hotmail.com 


\section{Pendahuluan}

Staphylococcus aureus merupakan bakteri kokus gram positif, memiliki genom kromosom sirkuler sekitar $2.800 \mathrm{~kb}$ (kilobasa) yang dapat membawa plasmid dan transposon. Infeksi yang ditimbulkan bakteri ini dapat diatasi dengan pemberian antimikrob golongan betalaktam seperti penisilin. Antimikrob betalaktam mengikat penicillin binding protein (PBP) sehingga sintesis dinding sel gagal dan bakteri mengalami lisis. ${ }^{1,2}$

Galur resisten $S$. aureus memiliki gen blaZ yang menyandi enzim betalaktamase, yaitu enzim yang mampu mendegradasi penisilin dengan cara memecah cincin betalaktam. Pada akhir tahun 1950-an, masalah resistensi terhadap betalaktam ini dapat diatasi dengan pemberian antimikrob yang tahan betalaktamase, yaitu metisilin. Isolat $S$. aureus yang peka terhadap metisilin disebut methicillin sensitive Staphylococcus aureus (MSSA). Sekitar satu tahun setelah penggunaan metisilin di rumah sakit, di Inggris ditemukan isolat $S$. aureus resisten metisilin yang disebut methicillin resistant Staphylococcus aureus (MRSA). ${ }^{3}$

Nama lain MRSA, yaitu healthcare acquired MRSA atau healthcare associated MRSA (HAMRSA), menyebar cepat ke seluruh rumah sakit di dunia dan memiliki fenotip multiresisten, yaitu resisten terhadap semua antimikrob betalaktam dan dua atau lebih antimikrob nonbetalaktam. ${ }^{4}$ Obat pilihan untuk terapi infeksi MRSA adalah vankomisin, tetapi pada tahun 1996 ditemukan penyebaran MRSA yang menurun kepekaannya terhadap vankomisin.

Data tahun 1998-1999 menunjukkan bahwa sekitar $25 \%$ isolat $S$. aureus penyebab infeksi di rumah sakit di Amerika Serikat adalah MRSA. ${ }^{6}$ Prevalensi MRSA di berbagai rumah sakit di dunia berkisar $2-70 \%$ dengan angka rata-rata $20 \% .{ }^{6-8}$ Prevalensi $<5 \%$ dijumpai di Belanda dan beberapa negara Skandinavia karena ketatnya penggunaan antimikrob serta keberhasilan program pengendalian infeksi MRSA. ${ }^{8}$ Noviana $^{9}$ melaporkan bahwa prevalensi MRSA di Rumah Sakit Atmajaya Jakarta pada tahun 2003 mencapai 47\%. Pada 1998, di Amerika Serikat ditemukan community-acquired MRSA atau communityassociated MRSA (CA-MRSA) ${ }^{10}$ yang tidak menunjukkan fenomena multiresisten serta lebih virulen dibandingkan dengan HA-MRSA karena membawa faktor virulen tambahan, yaitu protein panton valentin leukocidin (PVL). ${ }^{9,10}$

Ito dkk. ${ }^{11}$ menemukan, faktor yang mendasari resistensi MRSA adalah elemen genetik yang disebut Staphylococcal cassette chromosome mec (SCCmec). Mekanisme integrasi elemen genetik tersebut dan asalnya belum sepenuhnya diketahui. Gen mecA adalah bagian conserved pada elemen genetik SCCmec MRSA, menyandi PBP mutan PBP2a atau PBP2' seberat $76 \mathrm{kDa}$. Eksperimen dan eksplorasi genetik menunjukkan bahwa mekanisme resistensi MRSA terhadap antimikrob betalaktam diperankan oleh operon mecA yang memiliki organisasi, struktur, fungsi, dan mekanisme serupa dengan operon blaZ pada plasmid $S$. aureus produsen betalaktamase. Gen mecA menjadi baku emas identifikasi MRSA dengan polymerase chain reaction (PCR). ${ }^{11,12}$

Mekanisme resistensi MRSA terhadap antimikrob nonbetalaktam diduga didasari adanya bukti bahwa SCCmec mengandung transposon seperti Tn554 pada ujung 5' mecA dan insertion sequences seperti IS431 pada ujung $3^{\prime}$ mecA. ${ }^{13}$ Insertion sequences IS431 memiliki kemampuan rekombinasi dan menjadi determinan resistensi terhadap merkuri, kadmium, dan tetrasiklin. Gen lain yang berada di sekitar SCCmec seperti gen gyrA juga diduga berinteraksi dengan SCCmec mengakibatkan resistensi terhadap kuinolon. ${ }^{13}$

Berbagai temuan dalam 10 tahun terakhir menunjukkan perubahan pola distribusi MRSA, kepekaan terhadap berbagai antimikrob, dan kemungkinan perubahan pada tipe SCCmec. ${ }^{14,15}$ Berdasarkan uraian di atas, analisis tipe SCCmec dan hubungannya dengan pola kepekaan MRSA terhadap berbagai antimikrob penting dilakukan.

\section{Metode}

Desain penelitian adalah observasional analitik terhadap pembiakan MRSA, uji kepekaan antimikrob, dan typing SCCmec. Isolasi, identifikasi, dan deteksi MRSA dilakukan di Laboratorium Mikrobiologi Fakultas Kedokteran Universitas Padjadjaran, Bandung, sedangkan penentuan gen mecA dan typing SCCmec di Departemen Mikrobiologi Fakultas Kedokteran Universitas Sriwijaya, Palembang, periode Juli-Desember 2007.

Sampel berupa isolat bakteri dari Departemen Mikrobiologi Fakultas Kedokteran Universitas Padjadjaran, Bandung. Isolat standar atau kontrol 
adalah S. aureus ATTC 25923. Isolasi S. aureus menggunakan media agar darah, diinkubasi 24 jam pada suhu $37^{\circ} \mathrm{C}$. Dari isolat dibuat preparat apus dengan pewarnaan Gram dan uji koagulase untuk membedakan dari koagulase negatif staphylococcus (CoNS). Uji kepekaan terhadap antimikrob menggunakan produk Oxoid, UK, dengan metode difusi cakram media Mueller Hinton agar (MHA). Inokulasi dilakukan dengan sengkelit steril pada permukaan medium kemudian diletakkan cakram oksasilin $1 / 5 \mu \mathrm{g}$ dan diinkubasi 36 jam pada suhu $30^{\circ} \mathrm{C} .{ }^{16}$ Oksasilin dipilih karena lebih stabil, sensitif terhadap isolat heteroresisten, dan secara komersial tersedia di pasaran dibandingkan dengan metisilin. Cakram antimikrob beta laktam lainnya juga digunakan, yakni penisilin dan amoksisilin serta beberapa nonbetalaktam, yaitu eritromisin, norfloksasin, gentamisin, dan vankomisin. Pembacaan zona hambatan minimal dalam skala millimeter sesuai protokol CLSI tahun 2007..$^{17}$

Identifikasi MRSA dikonfirmasi melalui deteksi gen mecA dengan PCR, kemudian dilakukan typing SCCmec dengan PCR multipleks sesuai metode yang digunakan oleh Zhang dkk. ${ }^{18}$ Amplifikasi dilakukan dalam mesin $i$-cycler Biorad (Biorad System, USA) dengan denaturasi inisial $94^{\circ} \mathrm{C}$ selama 5 menit, 10 siklus $94^{\circ} \mathrm{C}$ selama 45 detik, $65^{\circ} \mathrm{C}$ selama 45 detik, dan $72^{\circ} \mathrm{C}$ selama 90 detik, kemudian 25 siklus $94^{\circ} \mathrm{C}$ selama 45 detik, $55^{\circ} \mathrm{C}$ selama 45 detik, $72^{\circ} \mathrm{C}$ selama 90 detik diikuti ekstensi final $72^{\circ} \mathrm{C}$ selama 10 menit sampai $4^{\circ} \mathrm{C}$. Pemeriksaan PCR pada target tunggal, misalnya SCC tipe III dilakukan dengan kondisi denaturasi inisial $94^{\circ} \mathrm{C}$ selama 5 menit diikuti 30 siklus $94^{\circ} \mathrm{C}$ selama 1 menit, $50^{\circ} \mathrm{C}$ selama 1 menit dan $72^{\circ} \mathrm{C}$ selama 2 menit serta ekstensi final $72^{\circ} \mathrm{C}$ selama 10 menit.

\section{Hasil}

Dilakukan uji kepekaan terhadap 45 isolat $S$. aureus pada media MHA untuk melihat pola kepekaan isolat tersebut terhadap tujuh macam antimikrob.

Presentase hasil uji kepekaan dapat dilihat pada Tabel 1. Semua isolat resisten terhadap oksasilin, berarti isolat tersebut adalah MRSA. Satu isolat ternyata telah resisten terhadap antimikrob golongan glikopeptida (vankomisin).

Ekstraksi DNA berhasil dilakukan pada semua isolat dengan metode rapid DNA extraction berdasarkan metode Zhang dkk. $^{18}$ Identifikasi MRSA dilakukan dengan deteksi gen mecA, yaitu sebesar 147 bp (base pair). Hasil

Tabel 1 Jumlah (Presentase) Isolat yang Sensitif (S) atau Resisten (R) terhadap Berbagai Antimikrob

\begin{tabular}{|c|c|c|c|c|c|c|c|}
\hline Kepekaan & Oxa & Pen & Amp & Van & Gen & Ery & Nor \\
\hline Sensitif (S) & $\begin{array}{ll}0 & (0)\end{array}$ & $1 \quad(2)$ & $1(2)$ & $44(98)$ & $5(11)$ & $5(11)$ & $\overline{5(11)}$ \\
\hline Resisten (R) & $45(100)$ & $44(98)$ & $44(98)$ & 1 (2) & $40(89)$ & $40(89)$ & $40(89)$ \\
\hline
\end{tabular}

Keterangan: Oxa: oksasilin/metisilin, Pen: penisilin, Amp: ampisilin, Van: vankomisin, Gen: gentamisin, Ery: eritromisin, Nor: norfloksasin



\section{Gambar 1 Hasil Identifikasi Gen mecA dengan Metode PCR}

Identifikasi ini dilakukan dengan elektroforesis pada gel agarosa $2 \%$ dan etidium bromida. Visualisasi dilakukan dengan alat Biorad Geldoc. Tampak amplikon sebesar 147 bp pada semua lajur kecuali lajur kontrol negatif (C) serta lajur 2 dan 4 (sampel MSSA sebagai pembanding) isolat tidak memiliki gen mecA 
Tabel 2 Hasil PCR Multipleks Tipe SCCmec Isolat MRSA

\begin{tabular}{ccc}
\hline & \multicolumn{3}{c}{ Jumlah } \\
\cline { 2 - 3 } Tipe SCCmec & Frekuensi & Persentase \\
\hline I & 0 & 0 \\
II & 0 & 0 \\
III & 40 & 89 \\
IV & 5 & 11 \\
\hline
\end{tabular}

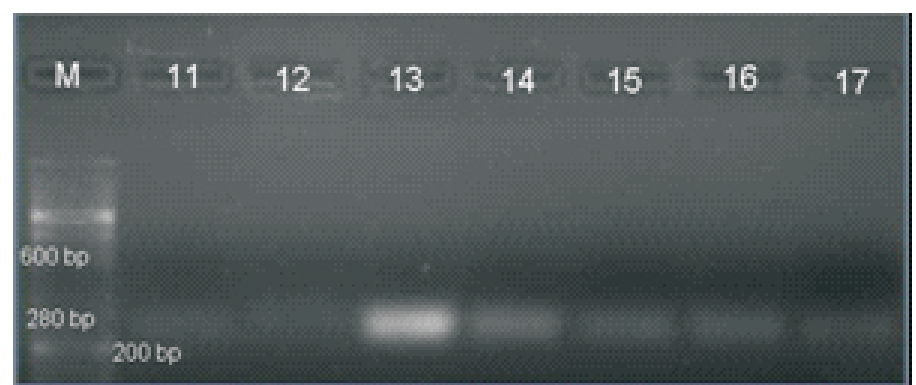

Gambar 2 Hasil PCR Multipleks Menunjukkan Pita DNA Sekitar 280 bp, yaitu SCC Tipe III



\section{Gambar 3 Hasil Identifikasi Gen SCCmec dengan Metode PCR Multipleks Menggunakan Sepasang Primer. Amplikon Terlihat dengan Jelas pada Posisi 490 bp yang Menunjukkan SCCmec Tipe IV}

yang didapatkan menunjukkan bahwa dari 45 isolat, seluruhnya $(100 \%)$ positif memiliki pita amplikon $147 \mathrm{bp}$ yang berarti seluruh isolat tersebut memiliki gen mecA. Seluruh amplikon kemudian diidentifikasi dengan PCR multipleks. Hasilnya dapat dilihat pada Gambar 1.

Hasil typing SCCmec dengan metode PCR multipleks terlihat pada Tabel 2 dan gambaran tipe SCCmec III dan IV terlihat pada Gambar 2 dan 3.

Tabel 3 memperlihatkan bahwa mayoritas isolat pada penelitian ini bersifat multiresisten.

\section{Pembahasan}

Semua isolat $S$. aureus resisten terhadap oksasilin dan $>80 \%$ resisten terhadap antimikrob lainnya, kecuali hanya satu isolat yang resisten terhadap vankomisin. Temuan ini sejalan dengan penelitian di Thailand, Singapura, serta beberapa negara Asia lainnya. Di Indonesia hal ini cukup menarik karena vankomisin belum digunakan secara luas, berarti paparan vankomisin terhadap populasi bakteri masih minimal. Isolat yang resisten tersebut kemungkinan karena mengalami mutasi spontan, terjadi akuisisi faktor resisten dari tempat lain, atau dari populasi bakteri enterokokus di sekitarnya. ${ }^{5}$

Penelitian ini juga menggambarkan bahwa jumlah isolat yang resisten terhadap antimikrob nonbetalaktam cukup tinggi. Resistensi terhadap aminoglikosida (gentamisin) dan makrolida (eritromisin) mencapai lebih dari 80\%. Resistensi terhadap kuinolon (norfloksasin) juga tinggi, lebih dari $70 \%$. Resistensi terhadap antimikrob nonbetalaktam terjadi terutama karena adanya 
interaksi berbagai determinan resisten pada $\mathrm{SCCmec}$ atau interaksi determinan resistensi yang berada di luar SCCmec dengan SCCmec. Gen aac6' dan gen erm pembawa resistensi terhadap eritromisin merupakan suatu bagian integral dari $\mathrm{SCC} m e c$. Gen gyr penentu resistensi terhadap kuinolon tidak berada dalam SCCmec tetapi berada di kromosom yang insersinya berdekatan dengan SCCmec. ${ }^{13}$

Mayoritas isolat pada penelitian ini bersifat multiresisten, hal ini sejalan dengan teori bahwa isolat yang berasal dari rumah sakit lebih bersifat multiresisten. Penelitian sebelumnya menyatakan demikian, bahkan studi di India menyebutkan bahwa sampai tahun 2004 semua isolat MRSA rumah sakit bersifat multiresisten. ${ }^{14}$ Temuan ini sesuai dengan hasil penelitian di 11 negara Asia termasuk Indonesia yang menyebutkan bahwa MRSA dari Indonesia (isolat dari Jakarta), India, Filipina, Saudi Arabia, Srilanka, China, Thailand, Singapura, serta Vietnam mayoritas mengandung SCCmec tipe III, sedangkan dari Korea dan Jepang SCCmec tipe II. ${ }^{19,20}$ Di luar Asia, SCCmec tipe III lazim ditemukan pada populasi Amerika Selatan, sedangkan SCCmec tipe II lazim ditemukan pada populasi Eropa. ${ }^{7}$ Makna penting dari hasil penelitian ini bahwa MRSA yang ditemukan mayoritas adalah isolat multiresisten, memiliki SCCmec yang lazim ditemukan di sebagian besar negara Asia dan Amerika Selatan. Secara umum dikatakan bahwa penggunaan antimikrob di wilayah tersebut tidak sebaik di Eropa Barat maupun Amerika Serikat. Regulasi dan penggunaan rasional antimikrob di klinik merupakan keadaan yang sudah sangat mendesak, supaya tidak terjadi induksi resistensi yang demikian cepat. Kekhawatiran tentang peningkatan isolat resisten, hasil tersebut juga mengindikasikan bahwa secara genetik MRSA dengan SCCmec tipe III bersifat lebih stabil dibandingkan dengan $\mathrm{SCCmec}$ tipe lainnya. Argumentasi yang ada sejauh ini adalah karena SCCmec tipe III berukuran paling besar sehingga relatif lebih stabil dari waktu ke waktu. ${ }^{11}$

Disimpulkan bahwa 40 isolat $S$. aureus memiliki SCCmec tipe III dan 5 isolat memiliki $\mathrm{SCCmec}$ tipe IV. Semua isolat yang memiliki SCCmec tipe III bersifat multiresisten dan semua isolat yang memiliki SCCmec tipe IV bersifat nonmultiresisten. Dari simpulan ini dapat dikatakan bahwa MRSA dengan genotip SCCmec tipe III berhubungan dengan sifat multiresisten, sedangkan MRSA dengan genotip SCCmec tipe IV berhubungan dengan sifat nonmultiresisten.

\section{Ucapan Terima Kasih}

Penelitian ini merupakan kolaborasi dengan Departemen Mikrobiologi Fakultas Kedokteran Universitas Sriwijaya Palembang, untuk itu penulis mengucapkan terima kasih kepada Yuwono yang telah membantu pelaksanaan pemeriksaan molekuler isolat pada penelitian ini.

\section{Daftar Pustaka}

1. Lowy FD. Staphylococcus aureus infection. N Engl J Med. 1998; 339:520-32.

2. Grayson ML. The treatment triangle for Staphylococcal infections. N Engl J Med. 2006;355:724.

3. Chambers HF. Methicillin resistant in staphylococci: molecular and biochemical basis and clinical implications. Clin Microbiol Rev. 1997;10: 781-9.

4. Lowy FD. Antimicrobial resistance: the example of Staphylococcus aureus. J Clin Invest. 2003; 111:1265-73.

5. Trakulsomboon S, Danchaivijitr S, Rongrungruang Y, Dhiraputra C, Susaemgrat W, Ito T, dkk. First report of methicillin resistant Staphylococcus aureus reduced susceptibility to vancomycin in Thailand. J Clin Microbiol. 2001; 39:591-5.

6. Bell JM,Turnidge JD. High prevalence of oxacillin-resistant Staphylococcus aureus isolates from hospitalized patients in Asia-Pacific and South Africa: results from SENTRY Antimicrobial Surveillance Program, 1998-1999. Antimicrob Agents Chemother. 2002;46:879-81.

7. Denis O, Deplano A, Nonhoff C, De Ryck R, de Mendonca R, Rottiers S, dkk. National Surveillance of methicillin-resistant Staphylococcus aureus in Belgian Hospitals indicates rapid diversification of epidemic clones. Antimicrob. Agents Chemother. 2004;48:3625-9.

8. Vos MC, Ott A, Verbrugh HA. Successful searchand-destroy policy for Methicillin-Resistant Staphylococcus aureus in the Netherlands J Clin Microbiol. 2005;43:2034-5.

9. Noviana H. Isolasi dan uji kepekaan isolat klinis ORSA dan nonORSA terhadap vankomisin dan antibiotik lainnya. J Mikrob Indon. 2004; 9:51-4.

10. Fey PD, Salim BS, Rupp ME, Hinrichs SH, Boxrud DJ, Davis CC, dkk. Comparative molecular analysis of community or hospital-acquired methicillin-resistant Staphylococcus aureus. Antimicrob Agents Chemother. 2003;47:196-203.

11. Ito $\mathrm{T}$, Katayama $\mathrm{Y}$, Asada K, Mori N, 
Tsutsumimoto K, Tiensasitorn C, dkk. Structural comparison of three types of Staphylococcal cassette chromosome mec integrated in the chromosome in methicillin-resistant Staphylococcus aureus. Antimicrob Agents Chemother 2001;45: 1323-36.

12. Ma XX, Ito $\mathrm{T}$, Tiensasitorn $\mathrm{C}$, Jamklang $\mathrm{M}$, Chongtrakool P, Boyle-Vavra S, dkk. Novel type of staphylococcal cassette chromosome mec identified in community-acquired methicillinresistant Staphylococcus aureus strains. Antimicrob Agents Chemother. 2002;46:1147-52.

13. Schmitz FJ, Fluit AC, Hafner D, Beeck A, Perdikouli M, Boos M, dkk. Development of resistance to ciprofloxacin, rifampin and mupirocin in methicillin susceptible and resistant S. aureus isolate. Antimicrob Agents Chemother. 2000;44: 3229-31.

14. Arakere G, Nadig S, Swedberg G, Macaden R, Amarnath SK, Raghunath D. Genotyping of methicillin-resistant Staphylococcus aureus Strains from two hospitals in Bangalore, South India. J Clin Microbiol. 2005;43:3198-202.

15. Okuma K, Iwakawa K, Turnidge JD, Grubb WB, Bell JM, O'Brien FG, dkk. Dissemination of new methicillin-resistant Staphylococcus aureus clones in the community. J Clin Microbiol. 2002; 40:4289-94.
16. Brown D, Cookson B. Detection of MRSA. Dalam: Fluit AC, Schmitz FJ, editor. MRSA: current perspectives. Norfolk England: Caister Academic Press; 2003. hlm. 11-30.

17. Clinical and Laboratory Standard Institute. Performance standards for antimicrobial susceptibility testing. Seventeenth Informational Supplement. 2007;27(1):M100-S17.

18. Zhang K, McClure J, Elsayed S, Louie T, Conly J. Novel multiplex PCR assay for characterization and concomitant subtyping of staphylococcal cassette chromosome mec types $\mathrm{I}$ to $\mathrm{V}$ in methicillin-resistant Staphylococcus aureus. J Clin Microbiol. 2005; 43:5026-33.

19. Chongtrakool $\mathrm{P}$, Ito $\mathrm{T}$, Ma XX, Kondo $\mathrm{Y}$, Trakulsomboon S, Tiensasitorn C, dkk. Staphylococcal cassette chromosome mec (SCCmec) typing of methicillin-resistant Staphylococcus aureus strains isolated in 11 Asian Countries: a proposal for a new nomenclature for SCCmec elements. Antimicrob Agents Chemother. 2006;50:1001-12.

20. Daum RS, Ito $\mathrm{T}$, Hiramatsu $\mathrm{K}$, Hussain $\mathrm{F}$, Mongkolrattanothai K, Jamklang M, dkk. Novel methicillin-resistance cassette in communityacquired methicillin-resistant Staphylococcus aureus isolates of diverse genetic backgrounds. J Infect Dis. 2002;186:1344-7. 